\title{
PENGARUH TINGKAT SUKU BUNGA TERHADAP YIELD TO MATURITY OBLIGASI DENGAN DIMEDIASI INFLASI (STUDI PADA PERUSAHAAN PERBANKAN YANG TERDAFTAR DI BURSA EFEK INDONESIA)
}

\author{
Sri Megawati Elizabeth *) \\ *) Sekolah Tinggi Ilmu Ekonomi Multi Data Palembang \\ Email: srimegawati@stie-mdp.ac.id
}

\begin{abstract}
The aims of this research are to know: (1) The effect of interest rate to yield to maturity,(2) The effect of inflation to yield to maturity, (3) The effect of interest rate to inflation, (4) The effect of interest rate to yield to maturity which mediated by inflation. The population of this research are 137 banking sector bonds. With purposive sampling technique, the sample used in this research are 25 banking sector bonds. The method of analysis used in this research is with path analysis and processed using SPSS. The results showed that the interest rate effect to yield to maturity, the interest rate influence to inflation, inflation does not affec to the yield to maturity, inflation mediates the absolute influence between the interest rate to yield to maturity.
\end{abstract}

Keywords: Interest, Yield to Maturity, Inflation, Bond

\section{PENDAHULUAN}

$\begin{array}{ccc}\text { Obligasi merupakan } & \text { suatu } \\ \text { bentuk instrument investasi } & \text { pasar }\end{array}$ modal berupa surat utang yang dikeluarkan oleh suatu perusahaan (emiten) untuk memperoleh sejumlah dana dan akan mengembalikan sejumlah uang tetap (pokok pinjaman) kepada pemegangnya pada saat jatuh tempo ditambah dengan pembayaran berupa kupon (Coupon) secara

Tabel. 1 Perkembangan Emisi Obligasi Korporasi dan Obligasi Pemerintah

\begin{tabular}{ccccc}
\hline Tahun & $\begin{array}{c}\text { Emiten } \\
\text { Obligasi } \\
\text { Korporasi }\end{array}$ & $\begin{array}{c}\text { Nilai } \\
\text { Emisi } \\
\text { Triliun Rp) }\end{array}$ & $\begin{array}{c}\text { Emiten } \\
\text { Obligasi } \\
\text { Pemerintah }\end{array}$ & $\begin{array}{c}\text { Nilai } \\
\text { Emisi } \\
\text { Triliun Rp) }\end{array}$ \\
\hline 2012 & 210 & 328.5 & 272 & 379.2 \\
2013 & 222 & 385.3 & 134 & 115.3 \\
2014 & 231 & 430 & 174 & 135.8 \\
2015 & 234 & 458 & 142 & 179.2 \\
\hline
\end{tabular}

Sumber: KSEI \& Kementrian Keuangan, 2017

Berdasarkan Tabel 1, bahwa perkembangan emiten jumlah obligasi korporasi lebih mengalami peningkatan dibandingkan obligasi pemerintah. Pada tahun 2015 terjadi peningkatan dengan jumlah 234 emiten dengan nilai emisi sebesar Rp 458 triliun sedangkan emiten obligasi pemerintah mengalami penurunan

dari tahun ke tahun. Hal ini menunjukkan periodik sesuai dengan perjanjian yang ditetapkan (Abudanti dan Sari, 2015).

$\begin{array}{clr}\text { Berikut } & \text { ini } & \text { disajikan } \\ \text { perkembangan } & \text { pasar } & \text { obligasi }\end{array}$ korporasi dan obligasi pemerintah dari jumlah emiten dan nilai emisi obligasi korporasi dan obligasi pemerintah dari tahun 2012 sampai 2015 pada Tabel 1 berikut ini: 
lain, dengan data sebagai berikut:

Tabel 2 Perkembangan Emisi Efek Per Sektor Jumlah Emiten Obligasi Sektor Tahun 2012 - 2015

\begin{tabular}{ccccccc}
\hline \multirow{2}{*}{ No. } & Klasifikasi Industri & \multicolumn{3}{c}{ Jumlah Emiten } & Nilai Emisi \\
\cline { 3 - 6 } & & $\mathbf{2 0 1 2}$ & $\mathbf{2 0 1 3}$ & $\mathbf{2 0 1 4}$ & $\mathbf{2 0 1 5}$ & (Triliun Rp) \\
\hline 1 & Pertanian & 10 & 10 & 10 & 11 & 23.94 \\
2 & Pertambangan & 1 & 2 & 2 & 2 & 27.50 \\
3 & Industri Dasar Kimia & 22 & 22 & 22 & 22 & 40.42 \\
4 & Aneka Industri & 9 & 9 & 9 & 9 & 13.04 \\
5 & Industri Barang \& Konsumsi & 11 & 11 & 11 & 12 & 62.36 \\
6 & Properti & 19 & 20 & 22 & 25 & 52.62 \\
7 & Infrastruktur & 16 & 15 & 16 & 19 & 218.95 \\
8 & Keuangan/Bank & 73 & 81 & 85 & 88 & 685.57 \\
9 & Perdagangan \& Investasi & 28 & 29 & 33 & 34 & 65.42 \\
\hline
\end{tabular}

Sumber: Otoritas Jasa Keuangan (2016)

Berdasarkan tabel diatas yang mendominasi adalah sektor keuangan /bank hal ini dikarenakan karena pada sektor keuangan lebih agresif daam menyikapi suku bunga dan selain itu sektor keuangan tidak terlepas dari kebutuhan permodalan perbankan dalam ekspansi jangka panjang. Sehingga hal ini dapat mengurangi kegagalan dalam pengelolaan antara sumber dana atau kekurangan dana yang mengakibatkan bank tidak mampu memenuhi kewajiban keuangan pada waktu yang telah ditetapkan karena sumber pendanaan perbankan berasal dari pihak ketiga. Hal ini menunjukkan bahwa obligasi korporasi pada sektor keuangan masih marak diperdagangkan di Indonesia.

Yield obligasi merupakan faktor terpenting untuk pertimbangan investor dalam melakukan pembelian obligasi sebagai instrumen investasinya. Pada dasarnya kondisi perkonomian mempengaruhi kondisi pasar. Faktor-faktor tersebut yaitu pertumbuhan produk domestik bruto (PDB), laju pertumbuhan inflasi dan tingkat suku bunga (Tandelilin, 20013). Menurut Jogiyanto (2010) dan Tandelilin (2001) salah satu faktor penentuan yield obligasi adalah tingkat bunga. Besarnya bunga yang ditawarkan oleh obligasi akan mempengaruhi tingkat keuntungan. Apabila tingkat suku bunga umum meningkat, maka yield obligasi akan turun, begitu sebaliknya jika tingkat suku bunga turun maka akan meningkatkan yield obligasi. Begitu juga dengan laju inflasi yang sangat fluktuatif berdampak pada investasi surat-surat berharga karena dengan inflasi yang meningkat berarti berinvestasi pada surat berharga seperti obligasi dirasa makin berisiko, tingginya risiko dalam investasi akan mengakibatkan semakin tinggi juga imbal hasil (yield) yang diharapkan oleh investor.

\section{Tujuann}

Penelitian ini bertujuan untuk menguji pengaruh tingkat suku bunga yang dimediasi oleh inflasi terhadap yield obligasi sektor perbankan yang terdaftar di Bursa Efek Indonesia Periode 20122015.

\section{Permasalahan}

1. Apakah Tingkat Suku Bunga mempengaruhi yield obligasi sektor perbankan?

2. Apakah Inflasi memediasi Tingkat Suku Bunga Terhadap Yield obligasi sektor perbankan? 


\section{LANDASAN TEORI}

\section{Yield Obligasi}

Yield to Maturity bisa diartikan sebagai tingkat pengembalian majemuk yang akan diterima investor jika membeli obligasi pada harga pasar saat ini dan menahan obligasi tersebut hingga jatuh tempo. Dalam menghitung yield to maturity menggunakan metode Internal Rate of Return (IRR) sebagai berikut: (Samsul, 2008)

$$
\begin{aligned}
& \text { Kurs }=\frac{\mathrm{C} 1}{(1+i)^{1}}+\frac{\mathrm{C} 2}{(1+i)^{2}}+\cdots \frac{\mathrm{Cn}}{(1+i)^{n}}+\frac{\mathrm{Tvn}}{(1+i)^{n} \ldots \ldots \ldots \ldots \ldots \ldots \ldots} \text { (1) } \\
& \text { TV = kurs jual atau nominal } \\
& (1+\mathrm{i})=1 \text { ditambah YTM yang akan dihitung } \\
& \mathrm{N} \quad=\text { jumlah frekuensi pembayaran kupon sampai maturity }
\end{aligned}
$$

\section{Tingkat Suku Bunga}

Investasi obligasi harus mempertimbangkan besar kecilnya tingkat suku bunga. Karena tingkat suku bunga berpengaruh terhadap imbal hasil (yield) obligasi yang akan diterima. Investor dapat menentukan suku bunga yang dapat dijadikan patokan sebelum membeli obligasi. Suku bunga yang dapat dijadikan benchmark terdiri atas berbagai jenis, salah satunya adalah tingkat suku bunga Bank Indonesia atau yang dikenal dengan $\mathrm{BI}$ rate. BI rate adalah suku bunga kebijakan yang mencerminkan sikap atau stance kebijakan moneter yang ditetapkan oleh Bank Indonesia dan diumumkan kepada publik (Bank Indonesia, 2017)

Inflasi adalah naiknya harga-harga komoditi secara umum yang disebabkan oleh tidak sinkronnya barang yang tersedia dengan tingkat pendapatan yang dimiliki oleh masyarakat. Dalam ilmu ekonomi, inflasi adalah suatu proses meningkatnya harga secara umum dan terus menerus.

Faktor-faktor yang mempengaruhi yield obligasi (Tandelilin, 2001) adalah: 1). Pertumbuhan produk domestik (PDB). 2). Laju pertumbuhan Inflasi. 3). Tingkat Suku Bunga. 4). Peringkat Obligasi.

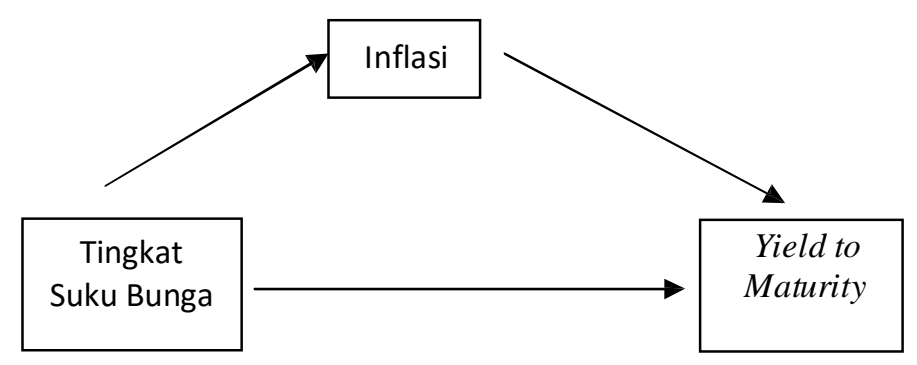

Gambar 1: Kerangka Konseptual 


\section{Pengembangan Hipotesis}

\section{Pengaruh Tingkat Suku Bunga Terhadap Yield Obligasi}

Tingkat suku bunga memiliki pengaruh terhadap yield obligasi. Hal ini juga sejalan dengan teori tingkat suku bunga, dimana ketika tingkat suku bunga meningkat, maka emiten obligasi akan memberikan tingkat yield yang lebih tinggi, sehingga harga dari obligasi di pasaran akan menurun dan begitu juga sebaliknya. Penelitian (Indarsih, 2013) juga menyatakan bahwa tingkat suku bunga berpengaruh positif dan signifikan terhadap yield to maturity obligasi.

H1: Tingkat Suku Bunga Berpengaruh Terhadap Yield Obligasi

\section{Pengaruh Inflasi Terhadap Yield Obligasi}

Inflasi merupakan salah satu hal yang perlu diperhatikan dalam melakukan investasi. Menurut penelitian yang dilakukan oleh (Lidya, 2010) mengatakan bahwa perubahan laju inflasi yang sangat fluktuatif berdampak pada investasi suratsurat berharga karena dengan inflasi yang meningkat berarti berinvestasi pada surat berharga seperti obligasi dirasa makin berisiko,tingginya risiko dalam investasi, akan mengakibatkan semakin tinggi juga imbal hasil (yield) yang diharapkan oleh investor.

H2: Inflasi Berpengaruh Terhadap Yield Obligasi

\section{Pengaruh Tingkat Suku Bunga Terhadap Inflasi}

Menurut teori kuantitas, kenaikan dalam tingkat pertumbuhan uang sebesar $1 \%$ menyebabkan kenaikan tingkat inflasi sebesar $1 \%$, sebaliknya kenaikan $1 \%$ tingkat inflasi akan menaikkan suku bunga nominal sebesar $1 \%$. Dari hal ini dapat dijelaskan bahwa suku bunga dan inflasi mempunyai hubungan yang positif. Jika tingkat inflasi tinggi maka tingkat bunga juga tinggi.

H3: Tingkat Suku Bunga Berpengaruh

Terhadap Inflasi

\section{Pengaruh Tingkat Suku Bunga Terhadap Yield yang diMediasi oleh Inflasi}

H4: Inflasi memediasi tingkat suku bunga terhadap yield to maturity

\section{METODE PENELITIAN}

Populasi penelitian ini adalah obligasi korporasi sebanyak 137 obligasi perusahaan sektor perbankan yang terdaftar di Bursa Efek Indonesia periode 2012-2015. Sampel dalam penelitian ini menggunakan purposive sampling yaitu teknik pengambilan sampel dengan berdasarkan kriteria-kriteria atau pertimbangan tertentu. Pemilihan sampel data dilakukan dengan memenuhi beberapa kriteria sebagai berikut: 1). Obligasi pada sektor perbankan yang tercatat selama 2012-2015 dalam Bond Book IDX. 2). Obligasi yang diterbitkan sektor perbankan selama 2012-2015. 3). Obligasi yang tidak memiliki laporan keuangan selama tahun 2012-2015. Sehingga jumlah sampel yang digunakan dalam penelitian ini berjumlah 25 obligasi sektor perbankan yang terdaftar di Bursa Efek Indonesia Periode 20122015.

\section{Analisis Data}

Penelitian ini menggunakan teknik analisis jalur (path analysis) dengan menggunakan data yang sebelumnya telah diuji dan memenuhi asumsi klasik.

$$
\begin{aligned}
& \text { Persamaan } 1 \\
& \text { Inflasi }=\mathbf{I}+\text { üTingkat Bunga }+ \text { ei ......(2) } \\
& \text { Persamaan } 2 \\
& \text { YTM }=\text { I }+ \text { üTingkat Bunga }+ \text { üinflasi }+ \text { ei } \\
& \ldots \ldots \ldots \ldots \ldots \ldots \ldots \ldots \ldots \ldots \ldots \ldots \ldots \ldots . \ldots \ldots \ldots \\
& \text { Dimana: } \\
& \text { Variabel Bebas } \\
& \text { Variabel Terikat : Tingkat Bunga } \\
& \text { Intervening : Inflasi }
\end{aligned}
$$




\section{HASIL DAN PEMBAHASAN}

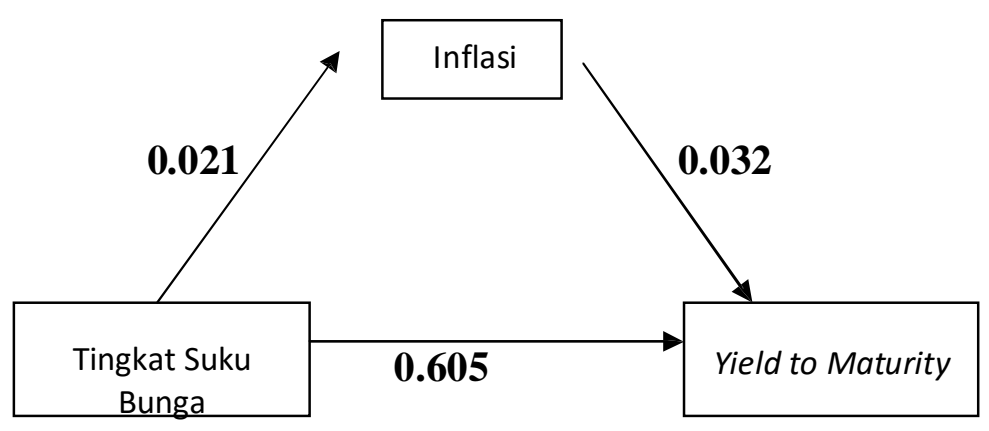

\section{Pengaruh Tingkat Suku Bunga Terhadap Yield to Maturity}

Dari hasil uji statistik didapat bahwa tingkat suku bunga berpengaruh positif dan signifikan terhadap Yield to maturity. Tingkat suku bunga memiliki pengaruh terhadap yield obligasi. Hal ini juga sejalan dengan teori tingkat suku bunga, dimana ketika tingkat suku bunga meningkat, maka emiten obligasi akan memberikan tingkat yield yang lebih tinggi, sehingga harga dari obligasi di pasaran akan menurun dan begitu juga sebaliknya. Hal ini juga didukung oleh penelitian yang dilakukan oleh Purnawati (2013) menyatakan bahwa tingkat suku bunga berpengaruh secara positif dan signifikan antara tingkat suku bunga terhadap yield obligasi.

\section{Pengaruh Tingkat Bunga Terhadap Inflasi}

Hasil pengujian secara statistik didapat bahwa tingkat bunga berpengaruh terhadap inflasi. Tingkat suku bunga cenderung akan meningkat pada saat inflasi yang diperkirakan meningkat. Kebijakan bunga rendah akan mendorong masyarakat untuk memilih investasi dan konsumsinya daripada menabung, sebaliknya kebijakan meningkatkan suku bunga simpanan akan menyebabkan masyarakat akan lebih banyak menabung daripada investasi atau konsumsi sehingga dapat diambil kesimpulan bahawa jika tingkat bunga rendah masyarakan lebih banyak melakukan kegiatan pada pasar modal dan sektor produktif lainnya dari pada menabung. Hal ini sejalan dengan penelitian yang dilakukan oleh (Heru Helambang,

Hasil pengujian secara statistik didapat bahwa inflasi tidak berpengaruh terhadap yield to maturity. Hal ini sejalan dengan penelitian yang dilakukan oleh (Oky Oktavian dkk,2015) menyatakan bahwa inflasi tidak berpengaruh terhadap yield

\section{Pengaruh Tingkat Bunga \\ Terhadap Yield to Maturity yang di Mediasi oleh Inflasi}

Hasil pengujian menunjukkan bahwa inflasi memediasi secara mutlak pengaruh antara tingkat suku bunga terhadap yield to maturity. Perubahan laju inflasi yang sangat fluktuatif yang akan memberi dampak pada investasi surat-surat berharga karena dengan inflasi yang meningkat berarti berinvestasi pada surat berharga seperti obligasi 
semakin beresiko yaitu tidak terbayarnya bunga dan pokok pinjaman karena kondisi pasar sedang mengalami kenaikan harga Inflasi yang meningkat akan mendorong tingkat bunga yang tinggi pula.

\section{KESIMPULAN}

Secara statistik tingkat suku bunga berpengaruh terhadap yield obligasi. Begitu juga tingkat bunga terhadap inflasi berpengaruh secara statistik. Sedangkan inflasi terhadap yield tidak berpengaruh. Namun inflasi memediasi secara mutlak pengaruh antara tingkat suku bunga terhadap yield.

Pasar obligasi akan menarik perhatian investor bila dalam kondisi perekonomian yang cenderung menurun dikarenakan tingkat bunga akan cenderung turun dan harga obligasi akan naik sehingga investor akan memperoleh keuntungan. Inflasi akan mengakibatkan penurunan nilai uang atau pendapatan yang diterima masyarakat. Sehingga dengan adanya kenaikan inflasi akan menyebabkan penurunan nilai riil pendapatan bunga yang diperoleh investor dan tingkat bunga tersebut akan mempengaruhi harga dan yield obligasi.

Jika tingkat bunga dimasa yang akan datang naik maka investor akan berbondong-bondong menginvestasikan dananya pada instrument jangka pendek untuk menghindari kerugian atau gagal bayar. Dalam memilih instrument investasi seperti obligasi sebaiknya para investor harus memperhatikan keadaan perekonomian seperti inflasi dan tingkat bunga karena hal ini akan sangat berpengaruh terhadap keuntungan (return) yang akan diperoleh di masa yang akan datang.

\section{DAFTAR PUSTAKA}

Ghozali, Imam. 2006, Aplikasi Analisis Multivariat dengan Program SPSS,
Semarang: BP UNDIP.

Heru, Helambang, 2010, Analisis Pengaruh Jumlah Uang Beredar, Suku Bunga, Nilai Tukar Terhadap Tingkat Inflasi Media Ekonomi Vol 19 No.2

Indarsih, Nanik, 2013, Pengaruh Tingkat Suku Bunga SBI, Rating, Likuiditas dan Maturitas Terhadap Yield to Maturity Obligasi, E-Jurnal Manajemen Universitas Negeri Surabaya. Jogiyanto Hartono, 2013, Teori Portofolio dan Analisis Investasi, BPFE Yogyakarta, Edisi Kedelapan

Nalurita Sari, Ni Wayan Linda \& Nyoman Abudanti, 2015. Variabel-Variabel yang Mempengaruhi Yield Obligasi Pada Perusahaan yang Terdaftar di Bursa Efek Indonesia. Jurnal Manajemen Unud, Bali Vol. 4, No. 11, 2015: 3796-3824.

Oky Oktavian, dkk (2015), Pengaruh Tingkat Inflasi, Debt to Equity Ratio, Likuiditas Obligasi dan Rating Obligasi Terhadap Yield Obligasi Korporasi Yang Terdaftar di Bursa Efek Indonesia (BEI) Tahun 2009-2012. Jom Fekon Vol. 2 No. 1.

Purnawati, I Gusti Ayu, 2013, Pengaruh Peringkat Obligasi, Tingkat Suku Bunga Sertifikat Bank Indonesia, Rasio Leverage, Ukuran Perusahaan dan Umur Obligasi pada Imbal Hasil Obligasi Korporasi di Bursa Efek Indonesia, Jurnal Riset Akuntansi Universitas Pendidikan Ganesha.

Samsul, Mohamad 2008, Pasar Modal dan Manajemen Portofolio, Jakarta: Erlangga. Suliyatno, 2011, Ekonomi Terapan : Teori \& Aplikasi dengan SPSS, Andi, Yogyakarta. Sugiyono, 2013, Metode Penelitian Manajemen, Alfabeta, Bandung.

Tandelilin, Eduardus . 2001, Analisis Investasi dan Manajemen Portofolio, Edisi 1, Cetakan kedua, Yogyakarta: BPFE. 
